\title{
Evaluatie vernieuwing rapportages meting 2005 : resultaten internetenquête onder hogescholen en universiteiten, najaar 2006
}

Citation for published version (APA):

Ramaekers, G. W. M. (2007). Evaluatie vernieuwing rapportages meting 2005 : resultaten internetenquête onder hogescholen en universiteiten, najaar 2006. Researchcentrum voor Onderwijs en Arbeidsmarkt, Faculteit der Economische Wetenschappen. ROA Working Papers No. 1 https://doi.org/10.26481/umarow.2007001

Document status and date:

Published: 01/01/2007

DOI:

10.26481/umarow.2007001

Document Version:

Publisher's PDF, also known as Version of record

Please check the document version of this publication:

- A submitted manuscript is the version of the article upon submission and before peer-review. There can be important differences between the submitted version and the official published version of record.

People interested in the research are advised to contact the author for the final version of the publication, or visit the DOI to the publisher's website.

- The final author version and the galley proof are versions of the publication after peer review.

- The final published version features the final layout of the paper including the volume, issue and page numbers.

Link to publication

\footnotetext{
General rights rights.

- You may freely distribute the URL identifying the publication in the public portal. please follow below link for the End User Agreement:

www.umlib.nl/taverne-license

Take down policy

If you believe that this document breaches copyright please contact us at:

repository@maastrichtuniversity.nl

providing details and we will investigate your claim.
}

Copyright and moral rights for the publications made accessible in the public portal are retained by the authors and/or other copyright owners and it is a condition of accessing publications that users recognise and abide by the legal requirements associated with these

- Users may download and print one copy of any publication from the public portal for the purpose of private study or research.

- You may not further distribute the material or use it for any profit-making activity or commercial gain

If the publication is distributed under the terms of Article $25 \mathrm{fa}$ of the Dutch Copyright Act, indicated by the "Taverne" license above, 


\section{Evaluatie vernieuwing rapportages meting 2005}

Resultaten internetenquête onder hogescholen en universiteiten, najaar 2006

ROA-W-2007/1

Ger Ramaekers

Researchcentrum voor Onderwijs en Arbeidsmarkt

Faculteit der Economische Wetenschappen en Bedrijfskunde Universiteit Maastricht

Maastricht, maart 2007 
ISBN 978-90-5321-453-4

Sec07.025 


\section{Inhoud}

Pagina

Inleiding 1

A. Evaluatie van de opzet $\quad 2$

$\begin{array}{ll}\text { B. Evaluatie van de vorm } & 7\end{array}$

$\begin{array}{ll}\text { C. Evaluatie van het gebruik } & 10\end{array}$

D. Evaluatie van de technische aspecten 12

$\begin{array}{ll}\text { Gemaakte slotopmerkingen } & 14\end{array}$

Bijlage: Inventarisatie van eerdere opmerkingen en suggesties $\quad 17$ 



\section{Inleiding}

In 2006 zijn de rapportages aan de hogescholen en universiteiten in het kader van de HBOen WO-Monitor 2005 ingrijpend gewijzigd. Dit om deze beter te laten aansluiten aan het accreditatiekader. Figuur 1 toont hoe de verschillende aspecten van de HBO- en WOMonitor 2005 zich verhouden tot het accreditatiekader en welke indicatoren voor de verschillende aspecten gebruikt zijn.

Figuur 1

Opbouw accreditatie en kwaliteitsindicatoren, meting 2005

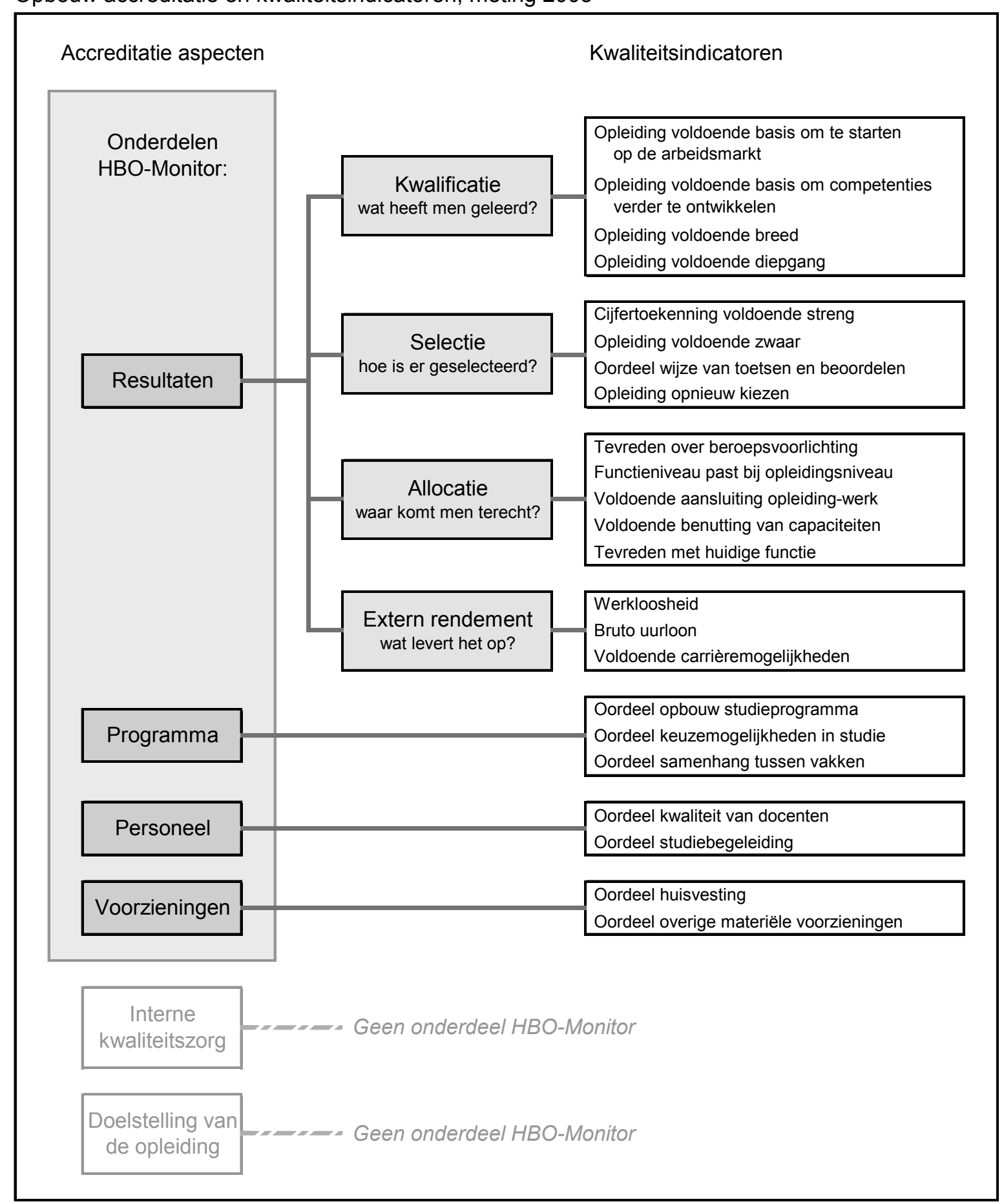


In de loop van 2006 zijn de vernieuwde rapportages aan de hogescholen en universiteiten uitgebreid geëvalueerd. Deze evaluatie omvatte een aantal activiteiten:

- presentaties en gesprekken met landelijke actoren (HBO-raad, VSNU, OCW, NQA, QANU, NVAO);

- gesprekken met locale gebruikers (onderwijsinstellingen);

- een evaluatie-onderzoek via internet onder alle universiteiten en deelnemende hogescholen

- tests op validiteit en betrouwbaarheid op basis van de naar aanleiding van de evaluatie bijgestelde vragenlijst.

In de hoofdtekst van dit rapport wordt verslag gedaan van de resultaten van het evaluatieonderzoek dat via internet onder alle universiteiten en deelnemende hogescholen is gehouden. In de bijlage staan de bevindingen uit de gesprekken met landelijke actoren en locale gebruikers. In een separaat Werkdocument staan de resultaten van de uitgevoerde tests op validiteit en betrouwbaarheid.

Aan het onderzoek via internet hebben 32 personen, afkomstig uit 15 hogescholen en 8 personen, afkomstig uit 6 universiteiten deelgenomen. ${ }^{1}$ Relatief groot is de deelname vanuit Avans Hogeschool en vooral Hogeschool INHOLLAND. Deze 2 hogescholen bepalen samen voor $41 \%$ het beeld voor het HBO. Vanuit 2 universiteiten hebben ieder 2 personen deelgenomen. Dit betekent dat deze 2 universiteiten voor de helft het beeld bepalen voor het WO.

\section{A. Evaluatie van de opzet}

1. Kunt u met een rapportcijfer een algemeen oordeel geven over de nieuwe opzet?

\section{Rapportcijfer voor de nieuwe opzet}

\begin{tabular}{lccc}
\hline & HBO & WO & Totaal \\
\hline Geen mening/niet bekend & 1 & 0 & 1 \\
5 & 0 & 1 & 1 \\
6 & 1 & 0 & 1 \\
7 & 8 & 1 & 9 \\
8 & 8 & 2 & 10 \\
Totaal & 18 & 4 & 22 \\
Gemiddeld rapportcijfer & 7,4 & 7,0 & 7,3 \\
Vraag niet beantwoord & 14 & 4 & 18 \\
& & & \\
\hline
\end{tabular}

Alleen de rapportcijfers die zijn genoemd, zijn opgenomen.

1. Daarnaast heeft nog één gebruiker van een hogeschool meegedaan. Deze gebruiker heeft echter slechts 2 vragen beantwoord, namelijk vraag 2 en vraag 12. Deze gebruiker heeft bij vraag 2 aangegeven dat de opzet sterk is verbeterd, en bij vraag 12 dat de vorm licht is verbeterd. 
Vrij veel gebruikers hebben deze vraag niet beantwoord. De gebruikers die de vraag wel hebben beantwoord, geven gemiddeld een ruim voldoende voor de nieuwe opzet van de rapportages.

2. Vindt $u$ dat de opzet in vergelijking met vroeger is verbeterd, gelijk gebleven of verslechterd?

Opzet verbeterd of verslechterd?

\begin{tabular}{lccc}
\hline & HBO & WO & Totaal \\
\hline Geen mening/niet bekend & 5 & 1 & 6 \\
- sterk verbeterd & 11 & 3 & 14 \\
- licht verbeterd & 12 & 1 & 13 \\
- gelijk gebleven & 2 & 3 & 5 \\
- licht verslechterd & 0 & 0 & 0 \\
- sterk verslechterd & 0 & 0 & 0 \\
Totaal & 30 & 8 & 38 \\
Vraag niet beantwoord & 2 & 0 & 2 \\
& & & \\
\hline
\end{tabular}

De meeste gebruikers in het $\mathrm{HBO}$ vinden dat de opzet in vergelijking met vroeger is verbeterd. In het WO vindt ongeveer de ene helft dat de opzet is verbeterd en de andere helft dat de opzet is gelijk gebleven.

\section{Accreditatiekader}

3. Wat is uw oordeel over de aansluiting tussen de rapportage en het accreditatiekader?

Oordeel over aansluiting tussen rapportage en accreditatiekader

\begin{tabular}{lrrr}
\hline & HBO & WO & Totaal \\
\hline Geen mening/niet bekend & 4 & 1 & 5 \\
- zeer goed & 1 & 0 & 1 \\
- goed & 17 & 4 & 21 \\
- voldoende & 9 & 2 & 11 \\
- slecht & 0 & 1 & 1 \\
- zeer slecht & 0 & 0 & 0 \\
Totaal & 31 & 8 & 39 \\
Vraag niet beantwoord & 1 & 0 & 1 \\
& & & \\
\hline
\end{tabular}

De meeste gebruikers in het HBO en WO oordelen positief over de aansluiting tussen de rapportage en het accreditatiekader: zij vinden de aansluiting voldoende of goed (vaker goed dan voldoende). 
4. Welke onderdelen vond u goed aansluiten en welke minder goed?

\subsection{Antwoorden van HBO-gebruikers}

Onderdelen die goed aansluiten bij het accreditatiekader:

Twaalf HBO-gebruikers hebben deze open vraag ingevuld. Hun antwoorden komen er op neer dat zij vinden dat de nieuwe opzet duidelijker is door de indeling in verschillende accreditatieaspecten. Een gebruiker miste "de maatschappelijke context".

Onderdelen die minder goed aansluiten bij het accreditatiekader:

Negen HBO-gebruikers hebben deze open vraag ingevuld. Zij noemden zaken als:

- vraagstelling sterker ontlenen aan landelijk vastgestelde beroepsprofielen;

- $\quad$ meer aandacht voor verworven inzichten en leervaardigheden;

- interne kwaliteitszorg (bijv. mate waarin studenten worden betrokken bij kwaliteitsverbetering en onderwijsontwikkeling);

- selectie, rendement;

- vervolgopleidingen;

- voorzieningen.

\subsection{Antwoorden van WO-gebruikers}

Onderdelen die goed aansluiten bij het accreditatiekader:

Twee WO-gebruikers hebben deze open vraag ingevuld. Hun antwoorden komen er op neer dat zij de aansluiting met het accreditatiekader goed vinden. Een van beiden merkte wel op dat soms nog wel wat onduidelijk is wat de betekenis van een cijfer is, omdat in de huidige rapportage de relatie tussen enquêtevraag en resultaat minder sterk is.

Onderdelen die minder goed aansluiten bij het accreditatiekader:

Eén WO-gebruiker heeft deze open vraag ingevuld. Hij/zij noemde competenties.

\section{Conceptueel kader}

5. Wat is uw oordeel over het conceptueel kader dat aan de opzet ten grondslag ligt?

Oordeel over het conceptueel kader

\begin{tabular}{lrrr}
\hline & HBO & WO & Totaal \\
\hline Geen mening/niet bekend & 7 & 1 & 8 \\
- zeer goed & 0 & 1 & 1 \\
- goed & 19 & 3 & 22 \\
- voldoende & 5 & 3 & 8 \\
- slecht & 0 & 0 & 0 \\
- zeer slecht & 1 & 0 & 1 \\
Totaal & 32 & 8 & 40 \\
& & & \\
\hline
\end{tabular}


De meeste gebruikers in het HBO en WO oordelen positief over het conceptueel kader dat ten grondslag ligt aan de nieuwe opzet van de rapportage: zij vinden het conceptueel kader voldoende of goed. Gebruikers in het HBO vinden het conceptueel kader vaker goed dan voldoende; gebruikers in het WO vinden het conceptueel kader ongeveer even vaak goed als voldoende.

\section{Vond $u$ bepaalde onderdelen overbodig of heeft $u$ bepaalde onderdelen gemist?}

\subsection{Antwoorden van HBO-gebruikers}

Onderdelen die overbodig worden gevonden:

Negen HBO-gebruikers hebben deze open vraag ingevuld. Zeven van hen vonden geen dingen overbodig. Een gebruiker wees op standaardteksten (met name over het lezen van de gegevens) die regelmatig worden herhaald. Een gebruiker tot slot vond alles overbodig.

Onderdelen die worden gemist:

Tien HBO-gebruikers hebben deze open vraag ingevuld. Vijf van hen hebben geen dingen gemist. De overige vijf gebruikers noemden de volgende dingen:

- mogelijkheid om zelf groepen te maken;

- iets uitgebreider over wat de alumni achteraf van de kwaliteit van de opleiding vonden en of ze nog zaken in de opleiding gemist hebben;

- de resultaten van andere opleidingen;

- $\quad$ kwaliteitszorg en oordeel van studenten over onderwijsvernieuwing

- de volledige scores op de competenties (dus niet alleen tekorten en overschotten weergeven).

\subsection{Antwoorden van WO-gebruikers}

Onderdelen die overbodig worden gevonden:

Drie WO-gebruikers hebben deze open vraag ingevuld. Twee van hen vonden geen dingen overbodig. De derde gebruiker wees op de lengte van de vragenlijst, en merkte op dat het rendement wellicht hoger is bij een kortere vragenlijst ("nu heel weinig antwoorden op heel veel vragen").

Onderdelen die worden gemist:

Twee WO-gebruikers hebben deze open vraag ingevuld. De een heeft geen dingen gemist. De andere merkte op dat meer aandacht voor competenties wenselijk is.

\section{Berekening indicatoren}

7. Wat is uw oordeel over de wijze waarop de indicatoren zijn berekend?

Over de wijze waarop de indicatoren zijn berekend, zijn de meeste gebruikers in het HBO en WO tevreden: zij vinden de operationalisering van de kwaliteitsindicatoren voldoende of goed (even vaak voldoende als goed). 


\begin{tabular}{lccc}
\hline & HBO & WO & Totaal \\
\hline Geen mening/niet bekend & 5 & 2 & 7 \\
- zeer goed & 1 & 0 & 1 \\
- goed & 12 & 2 & 14 \\
- voldoende & 12 & 2 & 14 \\
- slecht & 0 & 1 & 1 \\
- zeer slecht & 1 & 0 & 1 \\
Totaal & 31 & 7 & 38 \\
Vraag niet beantwoord & 1 & 1 & 2 \\
& & & \\
\hline
\end{tabular}

8. Heeft u suggesties voor een andere wijze van berekenen?

\subsection{Antwoorden van HBO-gebruikers}

Negen HBO-gebruikers hebben deze open vraag ingevuld. Drie van hen vulden in dat zij geen suggesties hebben. De overige zes gebruikers noemden de volgende dingen:

- berekening achterwege laten is veel beter;

- berekeningswijze beter toelichten (genoemd door 2 gebruikers);

- duidelijker aangeven wat de percentages precies betekenen;

- alumni met een functie buiten het beoogde werkveld buiten een aantal berekeningen houden;

- in ieder geval zorgen voor 20 of meer respondenten.

\subsection{Antwoorden van WO-gebruikers}

Eén WO-gebruiker heeft deze open vraag ingevuld. Hij merkte op dat de digitale versie van zijn instellingsrapportage geen bijlagen bevatte.

\section{Berekening rapportcijfers}

9. Wat is uw oordeel over de wijze waarop de rapportcijfers zijn berekend?

Oordeel over de berekening van de rapportcijfers

\begin{tabular}{lrrr}
\hline & HBO & WO & Totaal \\
\hline Geen mening/niet bekend & 5 & 2 & 7 \\
- zeer goed & 0 & 0 & 0 \\
- goed & 12 & 2 & 14 \\
- voldoende & 14 & 1 & 15 \\
- slecht & 0 & 0 & 0 \\
- zeer slecht & 1 & 0 & 1 \\
Totaal & 32 & 5 & 37 \\
Vraag niet beantwoord & 0 & 3 & 3 \\
& & & \\
\hline
\end{tabular}


Over de wijze waarop de rapportcijfers zijn berekend, zijn de meeste gebruikers in het HBO redelijk tevreden: zij vinden de operationalisering van de kwaliteitsindicatoren voldoende of goed (iets vaker voldoende dan goed).

10. Heeft u suggesties voor een andere wijze van berekenen?

\subsection{Antwoorden van HBO-gebruikers}

Acht HBO-gebruikers hebben deze open vraag ingevuld. Drie van hen vulden in dat zij geen suggesties hebben, en één gebruiker suggereerde om geen rapportcijfers te berekenen. De overige vier gebruikers noemden de volgende dingen:

- $\quad$ bij alle vragen een rapportcijfer laten geven, en dat op een of andere manier wegen om tot een rapportcijfer te komen;

- berekeningswijze beter toelichten;

- bij een aantal vragen verdisconteren dat alumni buiten het beoogde werkveld werken;

- $\quad$ rapportcijfers ook voor deeltijdopleidingen berekenen.

\subsection{Antwoorden van WO-gebruikers}

Eén WO-gebruiker heeft deze open vraag ingevuld. Hij verwees naar hetgeen hij bij vraag 8 had ingevuld, en merkte op dat hij vraag 10 niet kon invullen omdat zijn instelling geen bijlagen had ontvangen.

\section{B. Evaluatie van de vorm}

11a Kunt u met een rapportcijfer een algemeen oordeel geven over de nieuwe vorm van de overzichtsrapportage voor de gehele instelling.

Circa een derde van de HBO-gebruikers heeft geen mening over, of is niet bekend met, de overzichtsrapportage die voor de gehele instelling is opgesteld. Degenen die wel een rapportcijfer hebben gegeven voor de vorm van de overzichtsrapportage voor de hele instelling, beoordelen deze gemiddeld met (afgerond) een ruim voldoende.

Rapportcijfer voor de nieuwe vorm van de overzichtsrapportage voor de hele instelling

\begin{tabular}{lccc}
\hline & HBO & WO & Totaal \\
\hline Geen mening/niet bekend & 10 & 1 & 11 \\
1 & 1 & 0 & 1 \\
5 & 0 & 1 & 1 \\
6 & 4 & 2 & 6 \\
7 & 10 & 2 & 12 \\
8 & 7 & 2 & 9 \\
Totaal & 32 & 8 & 40 \\
Gemiddeld rapportcijfer & 6,9 & 6,7 & 6,8 \\
\hline
\end{tabular}

Alleen de rapportcijfers die zijn genoemd, zijn opgenomen. 
Opvallend is dat van de WO-gebruikers slechts een op de acht gebruikers geen mening heeft over (of niet bekend is met) de overzichtsrapportage die voor de gehele instelling is opgesteld (bij de HBO-gebruikers was dit een op de drie gebruikers). De WO-gebruikers die wel een rapportcijfer hebben gegeven voor de vorm van de overzichtsrapportage voor de hele instelling, beoordelen deze gemiddeld met (afgerond) een 6,7.

11b Kunt u met een rapportcijfer een algemeen oordeel geven over de nieuwe vorm van de Management Summary per sector/faculteit?

De HBO-gebruikers zijn beter bekend met de Management Summary die per sector/faculteit is gemaakt ('slechts' 2 geen mening/onbekend), dan met de overzichtsrapportage die voor de gehele instelling is opgesteld (liefst 10 geen mening/onbekend). Zowel de HBOgebruikers als de WO-gebruikers geven gemiddeld een ruim voldoende voor de vernieuwde vorm van de facultaire Management Summary.

Rapportcijfer voor de nieuwe vorm van de Management Summary per sector/faculteit

\begin{tabular}{lccc}
\hline & HBO & WO & Totaal \\
\hline Geen mening/niet bekend & 2 & 0 & 2 \\
1 & 1 & 0 & 1 \\
4 & 1 & 0 & 1 \\
6 & 5 & 3 & 8 \\
7 & 13 & 2 & 15 \\
8 & 9 & 3 & 12 \\
9 & 1 & 0 & 1 \\
Totaal & 32 & 8 & 40 \\
Gemiddeld rapportcijfer & 6,9 & 7,0 & 6,9 \\
\hline
\end{tabular}

Alleen de rapportcijfers die zijn genoemd, zijn opgenomen.

11c Kunt u met een rapportcijfer een algemeen oordeel geven over de nieuwe vorm van de digitale informatie per sector/faculteit?

Rapportcijfer voor de vorm van de digitale informatie per sector/faculteit

\begin{tabular}{lccc}
\hline & HBO & WO & Totaal \\
\hline Geen mening/niet bekend & 4 & 1 & 5 \\
1 & 1 & 0 & 1 \\
6 & 11 & 3 & 14 \\
7 & 4 & 2 & 6 \\
8 & 10 & 1 & 11 \\
9 & 1 & 0 & 1 \\
Totaal & 31 & 7 & 38 \\
Gemiddeld rapportcijfer & 6,8 & 6,7 & 6,8 \\
Vraag niet beantwoord & 1 & 1 & 2
\end{tabular}

Alleen de rapportcijfers die zijn genoemd, zijn opgenomen.

8 
Zowel bij de HBO-gebruikers als bij de WO-gebruikers heeft een op de acht gebruikers geen mening over (of is niet bekend is met) de digitale informatie die per sector/faculteit is verstrekt. Zowel de HBO-gebruikers als de WO-gebruikers waarderen de digitale informatie met gemiddeld bijna een ruim voldoende.

12. Vindt $u$ dat de vorm in vergelijking met vroeger is verbeterd, gelijk gebleven of verslechterd?

De meeste $\mathrm{HBO}-g e b r u i k e r s$ vinden dat de vorm van de rapportage in vergelijking met vroeger is verbeterd. WO-gebruikers zijn wat meer verdeeld in hun oordeel: 4 WOgebruikers vinden dat de vorm is verbeterd, en 3 WO-gebruikers dat de vorm is gelijk gebleven of zelfs verslechterd.

Vorm verbeterd of verslechterd?

\begin{tabular}{lrrr}
\hline & HBO & WO & Totaal \\
\hline Geen mening/niet bekend & 5 & 1 & 6 \\
- sterk verbeterd & 9 & 2 & 11 \\
- licht verbeterd & 13 & 2 & 15 \\
- gelijk gebleven & 3 & 2 & 5 \\
- licht verslechterd & 0 & 1 & 1 \\
- sterk verslechterd & 1 & 0 & 1 \\
Totaal & 31 & 8 & 39 \\
Vraag niet beantwoord & 1 & 0 & 1 \\
& & & \\
\hline
\end{tabular}

13. Heeft $u$ suggesties voor verbeteringen in de vorm van rapporteren?

\subsection{Antwoorden van HBO-gebruikers}

Zeven HBO-gebruikers hebben deze open vraag ingevuld. Twee van hen vulden in dat zij geen suggesties hadden. De overige vijf gebruikers deden suggesties m.b.t. de overzichtelijkheid van de rapportage, het presenteren van informatie per opleiding en het zelf rekenen met de data.

Suggesties die de overzichtelijkheid van de rapportering betreffen:

- Bij digitaal rapporteren aangeven in welke bijlage wat te vinden is;

- Minder bestanden!

Suggesties m.b.t. het presenteren van informatie per opleiding:

- Als het gaat om meerdere opleidingen binnen één 'instelling'(school) dan beter eerst de opleidingen apart, of liefst apart maar naast elkaar in 1 tabel (onderling vergelijkbaar kunnen maken), en dan het Schoolgemiddelde (is niet zulke relevante stuurinformatie;

- De resultaten per opleiding per vraag (in bijlagen) graag per opleiding één bestand met daarin alle vragen en resulaten van die opleiding. Nu moet je alles openen (van tevoren weet je niet welke vraag het is, de naam biedt hiervoor weinig handvatten;

Suggestie m.b.t. het zelf rekenen met de data: 
- Rapportage op hogeschoolniveau. De mogelijkheid om zelf te rekenen met de digitale database. De mogelijkheid om een overzicht per opleiding automatisch te genereren.

\subsection{Antwoorden van WO-gebruikers}

Eén WO-gebruiker heeft deze open vraag ingevuld. De suggestie was om informatie over bachelors en masters duidelijk te scheiden, en bij voorkeur alleen op masters te richten.

\section{Evaluatie van het gebruik}

\section{HBO-gebruikers}

Het minst geraadpleegd of gebruikt worden:

- de links vanuit de Management Summary naar de tellingen;

- de links;

- de meegeleverde bestanden (adressenbestand van de alumni en SPSS-bestand).

Het meest geraadpleegd of gebruikt worden:

- $\quad$ het pdf-document van de Management Summary;

- de tellingen (zowel op instellingsniveau als op opleidingsniveau);

- de tabel met informatie over wat individuele alumni na de opleiding zijn gaan doen.

De volgende onderdelen worden door de HBO-gebruikers het belangrijkst gevonden:

- de gedrukte en per post verzonden Management Summary;

- de tellingen op opleidingsniveau;

- de beide tabellen met de alumigegevens.

\section{HBO-gebruikers}

Onderdelen die $u$ (of een van uw collega's) heeft geraadpleegd of gebruikt (het gaat er niet om of $u$ van elke categorie alles heeft geraadpleegd)

$\begin{array}{cc}\text { Geraadpleegd } & \text { Belang van } \\ \text { of gebruikt } & \text { opname } \\ \text { ja nee GA } & \text { klein matig groot GA }\end{array}$

\section{Management Summary}

14. De links in de Management Summary naar de tellingen (vanuit de tabellen in hoofdstuk 3 en $\begin{array}{llllllll}4) & 10 & 20 & 2 & 2 & 9 & 6 & 15\end{array}$

15. Het pdf-document van de Management Summary

$\begin{array}{lllllll}21 & 10 & 1 & 1 & 7 & 13 & 11\end{array}$

16. De gedrukte en per post verzonden Management Summary

$\begin{array}{lllllll}16 & 14 & 2 & 4 & 2 & 14 & 12\end{array}$

\section{Tellingen}

17. Instellingsniveau

$\begin{array}{lllllll}20 & 11 & 1 & 2 & 5 & 15 & 10\end{array}$


Onderdelen die $u$ (of een van uw collega's) heeft geraadpleegd of gebruikt (het gaat er niet om of $u$ van elke categorie alles heeft geraadpleegd)

\begin{tabular}{cc}
$\begin{array}{c}\text { Geraadpleegd } \\
\text { of gebruikt } \\
\text { ja nee GA }\end{array}$ & \multicolumn{2}{c}{$\begin{array}{c}\text { Belang van } \\
\text { opname }\end{array}$} \\
\end{tabular}

18. Cluster/opleidingsniveau

$\begin{array}{lllllll}23 & 8 & 1 & 1 & 1 & 20 & 10\end{array}$

\section{Alumnigegevens}

19. Tabel 1 : informatie na opleiding

20. Tabel 2: contact met hogeschool

$\begin{array}{lllllll}21 & 11 & 0 & 2 & 3 & 16 & 11 \\ 16 & 16 & 0 & 3 & 3 & 15 & 11 \\ 7 & 18 & 7 & 2 & 6 & 4 & 20\end{array}$

\section{Links}

$7-18-7$

\section{Meegeleverde bestanden}

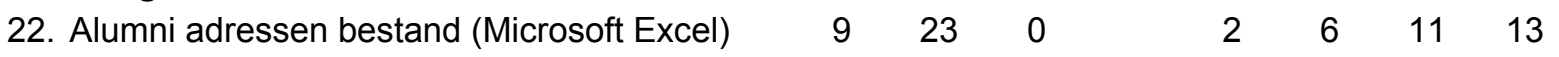

23. Databestand van respons (SPSS) $\quad \begin{array}{lllllll} & 93 & 0 & 5 & 4 & 9 & 14\end{array}$

GA: geen antwoord.

Kortom, HBO-gebruikers hechten de meeste waarde aan de Management Summary op papier, de tellingen en de 2 tabellen over individuele alumni.

\section{WO-gebruikers}

Het minst geraadpleegd of gebruikt worden de links en het adressenbestand van de alumni. Het meest geraadpleegd of gebruikt worden de tellingen (zowel op instellingsniveau als op opleidingsniveau).

De volgende onderdelen worden door de WO-gebruikers het belangrijkst gevonden:

- het pdf-document van de Management Summary;

- de tellingen op opleidingsniveau.

\section{WO-gebruikers}

Onderdelen die u (of een van uw collega's) heeft geraadpleegd of gebruikt (het gaat er niet om of u van elke categorie alles heeft geraadpleegd)

\begin{tabular}{ccc}
$\begin{array}{c}\text { Geraadpleegd } \\
\text { of gebruikt }\end{array}$ & \multicolumn{2}{c}{$\begin{array}{c}\text { Belang van } \\
\text { opname }\end{array}$} \\
ja nee GA klein matig groot GA
\end{tabular}

\section{Management Summary}

14. De links in de Management Summary naar de tellingen (vanuit de tabellen in hoofdstuk 3 en 4)

15. Het pdf-document van de Management Summary

$\begin{array}{lllllll}3 & 5 & 0 & 0 & 5 & 2 & 1 \\ 4 & 4 & 0 & 0 & 1 & 6 & 1\end{array}$




\section{WO-gebruikers}

Onderdelen die u (of een van uw collega's) heeft geraadpleegd of gebruikt (het gaat er niet om of u van elke categorie alles heeft geraadpleegd)

\begin{tabular}{ccc}
$\begin{array}{c}\text { Geraadpleegd } \\
\text { of gebruikt } \\
\text { ja nee GA klein matig groot GA }\end{array}$ \\
\hline
\end{tabular}

16. De gedrukte en per post verzonden

Management Summary

$\begin{array}{lllllll}3 & 5 & 0 & 1 & 1 & 3 & 3\end{array}$

\section{Tellingen}

17. Instellingsniveau

18. Cluster/opleidingsniveau

$\begin{array}{lllllll}5 & 2 & 1 & 0 & 3 & 4 & 1\end{array}$

$\begin{array}{lllllll}5 & 3 & 0 & 0 & 2 & 6 & 0\end{array}$

\section{Alumnigegevens}

19. Tabel 1: informatie na opleiding

$\begin{array}{lllllll}4 & 3 & 1 & 0 & 4 & 2 & 2\end{array}$

21. Links

$\begin{array}{lllllll}1 & 6 & 1 & 1 & 4 & 1 & 2\end{array}$

\section{Meegeleverde bestanden}

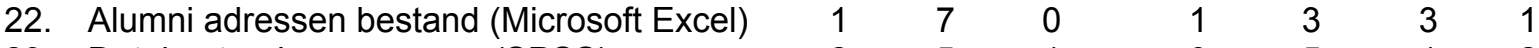

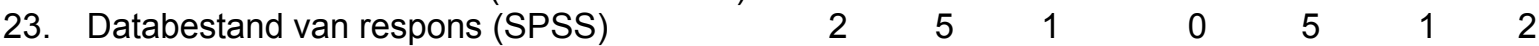

GA: geen antwoord.

\section{Evaluatie van de technische aspecten}

24. Heeft u moeite gehad met het installeren van de digitale versie van de instellingsrapportage?

Van de HBO-gebruikers hebben er 9 deze vraag niet beantwoord. Dit laat onverlet dat de meerderheid van de gebruikers, zowel bij $\mathrm{HBO}$ als bij WO, geen of weinig moeite heeft gehad met het installeren van de digitale versie van de instellingsrapportage.

Moeite met installeren van de digitale versie van de instellingsrapportage

\begin{tabular}{lrrr}
\hline & HBO & WO & Totaal \\
\hline - geen moeite & 11 & 3 & 14 \\
- weinig moeite & 8 & 2 & 10 \\
- veel moeite & 3 & 2 & 5 \\
- bijzonder veel moeite & 1 & 0 & 1 \\
Totaal & 23 & 7 & 30 \\
Vraag niet beantwoord & 9 & 1 & 10 \\
& & & \\
\hline
\end{tabular}


25. Kunt u via een rapportcijfer uw oordeel over het gebruiksgemak van de digitale rapportage geven?

Voor het gebruiksgemak van de digitale rapportage geven de HBO-gebruikers een voldoende tot ruim voldoende $(6,7)$. De WO-gebruikers zijn wat kritischer. Zij geven een 6,2 voor het gebruiksgemak van de digitale rapportage.

\section{Rapportcijfer voor het gebruiksgemak van de digitale rapportage}

\begin{tabular}{lccc}
\hline & HBO & WO & Totaal \\
\hline Geen mening/niet bekend & 4 & 0 & 4 \\
1 & 1 & 0 & 1 \\
4 & 1 & 0 & 1 \\
5 & 1 & 2 & 3 \\
6 & 5 & 1 & 6 \\
7 & 12 & 3 & 15 \\
8 & 5 & 0 & 5 \\
9 & 1 & 0 & 1 \\
Totaal & 30 & 6 & 36 \\
Gemiddeld rapportcijfer & 6,7 & 6,2 & 6,6 \\
Vraag niet beantwoord & 2 & 2 & 4 \\
\end{tabular}

Alleen de rapportcijfers die zijn genoemd, zijn opgenomen.

26. Heeft u suggesties om de technische aspecten / het gebruiksgemak te verbeteren?

\subsection{Antwoorden van HBO-gebruikers}

Tien HBO-gebruikers hebben deze open vraag ingevuld. Drie van hen vulden in dat zij geen suggesties hadden. Vier gebruikers deden de volgende suggesties om het gebruiksgemak te verhogen:

- Aanleveren als wordbestand;

- Tabellen ook als losse pdf-bestanden leveren;

- Informatie op papier;

- Ook een schriftelijke versie van zowel vt als dt.

De overige drie gebruikers deden de volgende suggesties:

- Beter aangeven in welke bijlage wat te vinden is;

- Digitale rapportages moeten op eigen intranet plaatsbaar zijn;

- Per opleiding één bestand met daarin alle vragen en resultaten van de betreffende opleiding.

\subsection{Antwoorden van WO-gebruikers}

Twee WO-gebruikers hebben deze open vraag ingevuld. Een gebruiker dacht dat hij/zij de digitale versie niet had gehad. De andere gebruiker hoefde niet alles te ontvangen ("het rapport en de adressen is voldoende"). 


\section{Gemaakte slotopmerkingen}

Zes HBO-gebruikers en drie WO-gebruikers hebben van de mogelijkheid gebruik gemaakt om onder het kopje "Opmerkingen" aan het einde van de vragenlijst nog iets op te merken. De gemaakte slotopmerkingen zijn hieronder integraal overgenomen.

\section{Slotopmerkingen van HBO-gebruikers}

- Graag zouden wij zien dat bij het trekken van de steekproef ook studenten in het buitenland en buitenlandse studenten betrokken zouden worden. Voor onze Internationale opleiding is dat van cruciaal belang!

- $\quad \mathrm{lk}$ vind het erg jammer dat kleine opleidingen niet zijn meegenomen, bijv de MiZ (voorheen KGZ) is in het hele bestand niet terug te vinden- een gemiste kans.

- Vraag over gebruik en belang meegeleverde bestanden: het was vrijwel onmogelijk gegevens na te zoeken door de onduidelijke variabelennamen. Een volgende keer zou ik graag variabelennamen op vraagnummer zien of tenminste een codeboek met de betekenis van de variabelennamen.

- Het belangrijkste vind ik de scores op de volledige competentielijst in de managementsamenvatting.

- Het is moderner geworden.

- $\quad$ Ik ben zeer tevreden over de nieuwe opzet van de HBO-monitor.

\section{Slotopmerkingen van WO-gebruikers}

- De WO-monitor is van weinig belang voor het beleid in mijn instelling. Daarentegen zijn oordelen van afgestudeerden dat wel maar WO-monitor is nu niet het goede instrument.

- Te weinig vergelijking van de eigen universiteit met andere universiteiten omdat daar vaak geen gegevens voor zijn, zo belangrijke grondslag voor ons verdwenen daarnaast zijn het slecht zeer basisachtige rapportages, zeer eenvoudig.

- Volgens mij zijn mijn antwoorden niet relevant voor dit onderzoek. Ik ben meer doorgeefluik dan dat ik actief wat met de gegevens doe. Neem mij dus maar niet mee bij de verwerking van de resultaten.

\section{Samenvatting gesloten vragen}

\begin{tabular}{|l|l|l|}
\hline & HBO-gebruikers & WO-gebruikers \\
\hline Aantal deelnemers & 32 uit 15 hogescholen & 8 uit 6 universiteiten \\
\hline Oordeel over nieuwe opzet & $\begin{array}{l}\text { Rapportcijfer } 7,4 . \\
\text { Meeste gebruikers vinden dan ook } \\
\text { dat de opzet in vergelijking met } \\
\text { vroeger is verbeterd }\end{array}$ & $\begin{array}{l}\text { Rapportcijfer } 7,0 . \\
\text { De ene helft vindt dat de opzet is } \\
\text { verbeterd en de andere helft dat } \\
\text { de opzet is gelijk gebleven }\end{array}$ \\
\hline $\begin{array}{l}\text { Oordeel over aansluiting met } \\
\text { accreditatiekader }\end{array}$ & $\begin{array}{l}\text { Meeste gebruikers vinden de } \\
\text { aansluiting voldoende of goed } \\
\text { (vaker goed dan voldoende) }\end{array}$ & $\begin{array}{l}\text { Meeste gebruikers vinden de } \\
\text { aansluiting voldoende of goed } \\
\text { (vaker goed dan voldoende) }\end{array}$ \\
\hline Oordeel over conceptueel & Meeste gebruikers vinden het & Meeste gebruikers vinden het \\
\hline
\end{tabular}




\begin{tabular}{|c|c|c|}
\hline & HBO-gebruikers & WO-gebruikers \\
\hline kader & $\begin{array}{l}\text { conceptueel kader voldoende of } \\
\text { goed (vaker goed dan voldoende) }\end{array}$ & $\begin{array}{l}\text { conceptueel kader voldoende of } \\
\text { goed (even vaak goed als } \\
\text { voldoende) }\end{array}$ \\
\hline $\begin{array}{l}\text { Oordeel over berekening } \\
\text { indicatoren }\end{array}$ & $\begin{array}{l}\text { Meeste gebruikers vinden de } \\
\text { berekening voldoende of goed } \\
\text { (even vaak goed als voldoende) }\end{array}$ & $\begin{array}{l}\text { Meeste gebruikers vinden de } \\
\text { berekening voldoende of goed } \\
\text { (even vaak goed als voldoende) }\end{array}$ \\
\hline $\begin{array}{l}\text { Oordeel over berekening } \\
\text { rapportcijfers }\end{array}$ & \begin{tabular}{|l|} 
Meeste gebruikers vinden de \\
berekening voldoende of goed \\
(iets vaker voldoende dan goed)
\end{tabular} & $\begin{array}{l}2 \text { gebruikers vinden het goed; } 1 \\
\text { gebruiker vindt het voldoende }\end{array}$ \\
\hline Oordeel over nieuwe vorm & $\begin{array}{l}\text { Meeste gebruikers vinden dat de } \\
\text { vorm is verbeterd }\end{array}$ & $\begin{array}{l}4 \text { gebruikers vinden dat de vorm is } \\
\text { verbeterd, en } 3 \text { gebruikers dat de } \\
\text { vorm is gelijk gebleven of zelfs } \\
\text { verslechterd }\end{array}$ \\
\hline Vorm overzichtsrapportage & Rapportcijfer 6,9 & Rapportcijfer 6,7 \\
\hline Vorm Management Summary & Rapportcijfer 6,9 & Rapportcijfer 7,0 \\
\hline Vorm digitale informatie & Rapportcijfer 6,8 & Rapportcijfer 6,7 \\
\hline Minst gebruikt & $\begin{array}{l}\text { Links } \\
\text { Links vanuit de tabellen naar de } \\
\text { tellingen } \\
\text { Meegeleverde bestanden }\end{array}$ & $\begin{array}{l}\text { Links } \\
\text { NAW-bestand alumni }\end{array}$ \\
\hline Meest gebruikt & $\begin{array}{l}\text { Tellingen } \\
\text { PDF van Management Summary } \\
\text { Activiteiten individuele alumni }\end{array}$ & Tellingen \\
\hline Meest relevant & $\begin{array}{l}\text { Gedrukte Management Summary } \\
\text { Tellingen op opleidingsniveau } \\
\text { Individuele alumni-gegevens }\end{array}$ & $\begin{array}{l}\text { PDF Management Summary } \\
\text { Tellingen op opleidingsniveau }\end{array}$ \\
\hline $\begin{array}{l}\text { Installeren digitale versie } \\
\text { rapportage }\end{array}$ & $\begin{array}{l}\text { Meerderheid geen of weinig } \\
\text { moeite }\end{array}$ & $\begin{array}{l}\text { Meerderheid geen of weinig } \\
\text { moeite }\end{array}$ \\
\hline $\begin{array}{l}\text { Oordeel over gebruiksgemak } \\
\text { digitale rapportage }\end{array}$ & Rapportcijfer 6,7 & Rapportcijfer 6,2 \\
\hline
\end{tabular}

\section{Samenvatting open vragen}

\begin{tabular}{|l|l|l|}
\hline Onderwerp & Antwoord van gebruikers & Actie door ROA/Desan \\
\hline $\begin{array}{l}\text { Onderdelen die minder goed } \\
\text { aansluiten bij accreditatiekader }\end{array}$ & $\begin{array}{l}\text { Vraagstelling ontlenen aan } \\
\text { landelijk vastgestelde } \\
\text { beroepsprofielen }\end{array}$ & $\begin{array}{l}\text { Bestaat reeds voor kuo } \\
\text { wordt in meting 2006 getest in } \\
\text { een10\%-steekproef bij het heo }\end{array}$ \\
\hline & Competenties & $\begin{array}{l}\text { Kennisinformatie over } \\
\text { competenties wordt beter } \\
\text { ontsloten in nieuwe opzet. } \\
\text { Werkgroep meten van } \\
\text { competenties ingesteld die in } \\
\text { 2008 tot aanpassing van de } \\
\text { vraagstelling moet leiden }\end{array}$ \\
\hline & Selectie & In vragenlijst 2006 items \\
\hline
\end{tabular}




\begin{tabular}{|c|c|c|}
\hline Onderwerp & Antwoord van gebruikers & Actie door ROA/Desan \\
\hline & & $\begin{array}{l}\text { opgenomen t.a.v. het facet } \\
\text { Beoordeling en toetsing van het } \\
\text { aspect Programma van het } \\
\text { accreditatiekader }\end{array}$ \\
\hline \multirow[t]{2}{*}{ Gemist in opzet } & $\begin{array}{l}\text { Mogelijkheid om zelf groepen te } \\
\text { maken, zelf te rekenen met } \\
\text { digitale database, overzicht per } \\
\text { opleiding zelf te genereren }\end{array}$ & $\begin{array}{l}\text { Mogelijkheid om zelf groepen } \\
\text { samen te stellen/te rekenen met } \\
\text { digitale database wordt in de } \\
\text { volgende meting aangeboden }\end{array}$ \\
\hline & $\begin{array}{l}\text { Uitgebreider oordeel over } \\
\text { kwaliteit opleiding }\end{array}$ & $\begin{array}{l}\text { Vragenlijst } 2006 \text { afgestemd op } \\
\text { het aspect Programma van het } \\
\text { accreditatiekader }\end{array}$ \\
\hline \multirow[t]{2}{*}{ Berekening indicatoren } & Beter/duidelijker toelichten & $\begin{array}{l}\text { Berekeningswijze wordt } \\
\text { vereenvoudigd. }\end{array}$ \\
\hline & $\begin{array}{l}\text { Alumni met werk buiten beoogd } \\
\text { werkveld buiten aantal } \\
\text { berekeningen houden }\end{array}$ & $\begin{array}{l}\text { In een aparte tabel in de } \\
\text { Management Summary wordt } \\
\text { voor de indicatoren voor } \\
\text { kwalificatie, allocatie (excl. } \\
\text { functieniveau) en extern } \\
\text { rendement (excl. werkloosheid) } \\
\text { een onderscheid gemaakt } \\
\text { tussen: werk op niveau en } \\
\text { binnen richting, werk op niveau } \\
\text { en buiten richting, werk onder } \\
\text { niveau }\end{array}$ \\
\hline $\begin{array}{l}\text { Management Summary / } \\
\text { berekening rapportcijfers }\end{array}$ & $\begin{array}{l}\text { Ook voor deeltijdopleidingen } \\
\text { berekenen }\end{array}$ & Wordt uitgevoerd \\
\hline \multirow[t]{2}{*}{ Verbetering gebruiksgemak } & $\begin{array}{l}\text { Rapportage ook aanleveren als } \\
\text { wordbestand }\end{array}$ & Wordt uitgevoerd \\
\hline & $\begin{array}{l}\text { Beter aangeven in welke bijlage } \\
\text { wat te vinden is }\end{array}$ & Wordt uitgevoerd \\
\hline
\end{tabular}




\section{Bijlage: Inventarisatie van eerdere opmerkingen en suggesties}

\begin{tabular}{|c|c|c|}
\hline Onderwerp & $\begin{array}{l}\text { Gemaakte opmerking / } \\
\text { suggestie voor verbetering }\end{array}$ & Actie door ROA/Desan \\
\hline \multirow[t]{4}{*}{ Tekstueel } & $\begin{array}{l}\text { Voor het WO de term } \\
\text { instellingsrapportage vervangen } \\
\text { door faculteitsrapportage, en de } \\
\text { term 'instelling' (bijvoorbeeld } \\
\text { boven kolommen) vervangen door } \\
\text { 'faculteit'. }\end{array}$ & Wordt uitgevoerd \\
\hline & $\begin{array}{l}\text { In Management Summary met } \\
\text { bijvoorbeeld plussen of minnen } \\
\text { aangeven of significant boven of } \\
\text { onder het gemiddelde wordt } \\
\text { gescoord (i.v.m. fotokopiëren). }\end{array}$ & Wordt uitgevoerd \\
\hline & $\begin{array}{l}\text { In de tabel "Vereiste competenties } \\
\text { en eigen niveau" de term } \\
\text { "overschot" (is een negatieve } \\
\text { term) vervangen door "surplus". }\end{array}$ & Wordt uitgevoerd \\
\hline & $\begin{array}{l}\text { In de bijlage met het conceptueel } \\
\text { model een zin opnemen dat } \\
\text { efficiëntie alleen relevant is als het } \\
\text { effectief is. }\end{array}$ & Wordt uitgevoerd \\
\hline \multirow[t]{5}{*}{ Berekeningswijze } & $\begin{array}{l}\text { Gehanteerde rekenmethode } \\
\text { omslachtig en norm arbitrair. } \\
\text { Het stelselmatig toerekenen van } \\
\text { oordeel } 3 \text { op 5-punstsschalen naar } \\
\text { de "positieve" kant leidt tot een te } \\
\text { rooskleurig beeld. }\end{array}$ & $\begin{array}{l}\text { Berekening rapportcijfers wordt } \\
\text { vereenvoudigd. Ook de } \\
\text { normering wordt aangepast. }\end{array}$ \\
\hline & $\begin{array}{l}\text { i.v.m. landelijke benchmark } \\
\text { aangeven op hoeveel opleidingen } \\
\text { met hoeveel respondenten de } \\
\text { landelijke cijfers betrekking } \\
\text { hebben. }\end{array}$ & Wordt uitgevoerd \\
\hline & $\begin{array}{l}\text { Sterke twijfels over de } \\
\text { minimumgrens van } 20 \\
\text { respondenten. }\end{array}$ & $\begin{array}{l}\text { Minimumgrens blijft } \\
\text { gehandhaafd (zie technisch } \\
\text { werkdocument) }\end{array}$ \\
\hline & $\begin{array}{l}\text { Betrouwbaarheidsintervallen/range } \\
\text { van scores aangeven. }\end{array}$ & $\begin{array}{l}\text { Wordt niet opgevolgd (te } \\
\text { onbegrijpelijk voor meeste } \\
\text { gebruikers) }\end{array}$ \\
\hline & $\begin{array}{l}\text { Trendcijfers: het gemiddelde over } \\
\text { alle respondenten berekenen (dus } \\
\text { niet het gemiddelde van de } \\
\text { jaartotalen). }\end{array}$ & Wordt uitgevoerd \\
\hline Gebruiksgemak & $\begin{array}{l}\text { Vragenlijst voorzien van } \\
\text { variabelennamen. }\end{array}$ & Wordt uitgevoerd \\
\hline \multirow[t]{2}{*}{ Onduidelijkheden } & $\begin{array}{l}\text { In de tabellen beter aangeven } \\
\text { waar de indicatoren op slaan. }\end{array}$ & Wordt uitgevoerd \\
\hline & $\begin{array}{l}\text { Gebruikersinstructie moet } \\
\text { duidelijker. }\end{array}$ & Wordt uitgevoerd \\
\hline
\end{tabular}




\begin{tabular}{|c|c|c|}
\hline Onderwerp & $\begin{array}{l}\text { Gemaakte opmerking / } \\
\text { suggestie voor verbetering }\end{array}$ & Actie door ROA/Desan \\
\hline & $\begin{array}{l}\text { De passage over zuiver } \\
\text { vergelijken is blijkbaar niet } \\
\text { duidelijk. }\end{array}$ & Wordt bekeken \\
\hline \multirow[t]{5}{*}{ Indicatoren } & $\begin{array}{l}\text { De selectiefunctie moet verder } \\
\text { uitgewerkt worden. Uitbreiding van } \\
\text { de selectiefunctie moet niet } \\
\text { gezocht moet worden met } \\
\text { indicatoren op het gebied van } \\
\text { rendement en uitval. }\end{array}$ & $\begin{array}{l}\text { Vragenlijst is inmiddels } \\
\text { bijgesteld (met indicatoren over } \\
\text { de betrouwbaarheid van het } \\
\text { selectieproces) }\end{array}$ \\
\hline & $\begin{array}{l}\text { Indicatoren over personeel en } \\
\text { vooral voorzieningen horen eerder } \\
\text { thuis in een } \\
\text { tevredenheidonderzoek onder } \\
\text { studenten dan in een } \\
\text { afgestudeerdenonderzoek. }\end{array}$ & $\begin{array}{l}\text { Vragenlijst is inmiddels } \\
\text { bijgesteld }\end{array}$ \\
\hline & $\begin{array}{l}\text { Het is niet duidelijk wat precies } \\
\text { bedoeld wordt met de 'wijze van } \\
\text { toetsen en beoordelen'. Het is } \\
\text { beter om te vragen of } \\
\text { er bij groepswerk voldoende } \\
\text { maatregelen zijn genomen om } \\
\text { meeliften te voorkomen. }\end{array}$ & $\begin{array}{l}\text { De 'wijze van toetsen en } \\
\text { beoordelen' is vervallen als } \\
\text { indicator van het aspect } \\
\text { Programma, en in de vragenlijst } \\
\text { is de vraag opgenomen hoe } \\
\text { makkelijk het is voor studenten } \\
\text { om bij groepswerk mee te liften. }\end{array}$ \\
\hline & $\begin{array}{l}\text { Er zou moeten worden nagegaan } \\
\text { of er nog witte vlekken zijn m.b.t. } \\
\text { het accreditatiekader. Bijvoorbeeld } \\
\text { bij 'kwaliteit van docenten'. }\end{array}$ & $\begin{array}{l}\text { Is inmiddels gedaan, en } \\
\text { vragenlijst is inmiddels } \\
\text { bijgesteld }\end{array}$ \\
\hline & $\begin{array}{l}\text { De spijtvraag (de vraag of je de } \\
\text { opleiding nog een keer zou doen } \\
\text { als je opnieuw moest kiezen) is } \\
\text { niet eenduidig en kan niet altijd } \\
\text { worden gerelateerd aan de } \\
\text { kwaliteit van de opleiding. }\end{array}$ & $\begin{array}{l}\text { De spijtvraag wordt uit de } \\
\text { selectiefunctie gehaald, en als } \\
\text { aparte 'algehele } \\
\text { tevredenheidsindicator' } \\
\text { gepresenteerd. }\end{array}$ \\
\hline Instrument & $\begin{array}{l}\text { Er zou een werkgroep inhoudelijke } \\
\text { en methodologische mensen bij } \\
\text { elkaar moeten worden geroepen } \\
\text { om de logica en consistentie van } \\
\text { de HBO-Monitor te verbeteren. }\end{array}$ & $\begin{array}{l}\text { Werkgroep is inmiddels } \\
\text { ingesteld, die zich in eerste } \\
\text { instantie zal richten op het } \\
\text { inhoudelijk en methodologisch } \\
\text { verantwoord meten van } \\
\text { competenties }\end{array}$ \\
\hline
\end{tabular}

